RESEARCH ARTICLE

\title{
Development and Evaluation of Solenoid-Actuated Check Valve for Electro-Mechanical Inclined Plate Metering System Under Laboratory Conditions
}

\author{
Jany Giles, $A^{* 1}$ and Surendrakumar, $A^{2}{ }^{2}$ \\ ${ }^{1}$ Department of Farm Machinery and Power Engineering, Agricultural Engineering College \& Research Institute, \\ Tamil Nadu Agricultural University, Kumulur, Trichy-621 712 \\ ${ }^{2}$ Department of Farm Machinery and Power Engineering, Agricultural Engineering College \& Research Institute, \\ Tamil Nadu Agricultural University, Coimbatore-641 003
}

\begin{abstract}
The seeds in the conventional seed metering mechanism are metered and transferred through seed tube to the furrow created by the furrow opener. In this type of delivery, non-uniformity occurs due to the uncontrolled seed falling through seed tube from the metering device to the furrow. In conventional precision planters, the seed rate is controlled, whereas placement of seeds in furrow cannot be controlled. To achieve control over seed placement in the furrow, the solenoid-actuated check valves have been developed and fixed to the electro mechanical inclined metering system. The check valve system was tested with an opto electronic measurement system in laboratory conditions. For $\mathrm{CO} 6$ variety of maize seeds, the quality feed index, missing index, multiple index and precision indexes found out as $86.2-89.6 \%$, $8-11.8 \%, 1.9-2.9 \%$ and 14.6 to $16.5 \%$, respectively. Using solenoidactuated check valve, the precision index of the developed electro mechanic metering system (14.6 - $16.5 \%)$ increased.
\end{abstract}

Keywords: solenoid actuated check valve; linear solenoid actuator; opto electronic measurement system; electromechanical drive; inclined plate metering

\section{INTRODUCTION}

In precision planting of maize, uniform planting pattern can be achieved by the metering mechanism, which maintains the uniform plant to plant distance in each traveling pass (Özmerzi et al., 2002). The plant population over a unit area is necessary to obtain good yield. This can be achieved by changing metering plates in the chain drive metering mechanism and involves higher manufacturing and operating costs of the planter (Cay et al., 2018).

In conventional seed metering mechanism, the seeds are metered and transferred to the furrow created by the furrow opener via a seed tube. Due to the uncontrolled seed falling through the seed tube from the metering device to the furrow and bouncing of the seeds and vibrations induced by the planter at higher travelling speed, the non-uniformity of seed spacing between the plants will have occurred. In conventional precision planters, the planter can control the seed population, but it has no control over the actual timing and placement of the seed. The important disadvantage of conventional precision planters is the lack of communication of seed placement between components of the planter, resulting in the absence of detection on time and place of seed relative to neighboring row units (lacomi \& Popescu, 2015). To minimize seed dispersion and scattering of seeds in the furrow, rotary valves and reciprocating valves are used in hill dropping of seeds (Bainer et al., 1956). In the check row planters, the reciprocating valves can also be used for hill dropping. The valves are in closed default position and store the seed. On-time intervals, the valves will open and release the seed in the furrow.

Performance of the metering mechanism depends on the transmission system by which the metering mechanism runs (Liang et al., 2015). Another limitation involved in chain drive metering mechanism was poor performance in higher travelling speeds. In existing precision planters, mechanical transmission system is used to transmit the motion from the ground wheel to seed metering mechanism

Gautam, 2017 studied the microcontrollerbased seed metering mechanism for pulse crops and introduced electro mechanical seed metering drive to increase the operating performance of 
metering mechanism. The study reported a quality feed index of $90 \%$ at forward speed of $1.56 \mathrm{~km} \mathrm{~h}^{-1}$ and $5.4 \mathrm{~mm}$ cell diameter. Cay et al., 2018 studied the performance of electro-mechanic drive systems for precision planters at various levels of operating speed $\left(5,7.5,10 \mathrm{~km} \mathrm{~h}^{-1}\right)$ and ten number of seed spacings $(6-29.3 \mathrm{~cm})$ at laboratory conditions. Quality of feed index $\left(I_{\mathrm{qf}}\right)$, multiple index $\left(I_{\text {multi }}\right)$, miss index $\left(I_{\text {miss }}\right)$ and precision index $\left(I_{p}\right)$ were in the range of $2.91-95.36 \%, 0-1.73 \%, 4.45-97.09 \%$ and 8.79 - $22.14 \%$, respectively when using electromechanic drive system.

Among the precision planters, the inclined plate metering mechanism is commonly used and widely manufactured metering mechanism in India. Various performance studies were conducted on inclined plate metering mechanism. Singh et al., 2020 evaluated the inclined plate seed metering mechanism for maize in laboratory conditions. The quality of feed index was obtained as 83.38 $\%, 87.20 \%$ and $85.40 \%$ respectively for $\mathrm{PMH}-1$, PIONEER-3396 and $\mathrm{PMH}-10$ varieties.

Keeping these points in view, it was aimed to develop the solenoid actuated check valve for electro- mechanical inclined plate metering system. The developed solenoid-actuated check valve is evaluated to study the effects of check valve operating speed on seed spacing in laboratory conditions.

\section{MATERIAL AND METHODS}

\section{Solenoid coil operated check valve}

\section{Construction}

To increase the precision of seed placement in the furrow, the solenoid-actuated check valves are introduced in the seed metering system. It was placed near the furrow and at the end of the seed tube. It consists electromagnetic linear solenoid actuator, seed tube and check valve door, as depicted in Fig. 1. The check valve door holds the seed from seed metering mechanism. When the signal is received from the control system at every plant spacing, the solenoid coil will energize and pull the check valve door attached to it for delivering the seed at correct plant spacing. The end of the seed tube was cut at an angle of $70^{\circ}$ from horizontal to minimize the check valve door opening degree from vertical.

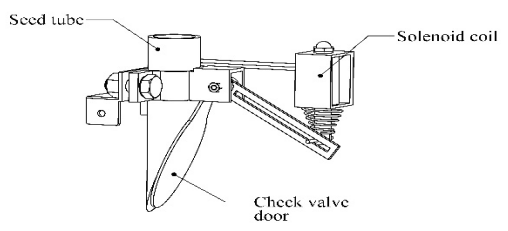

Figure. 1Schematic diagram of solenoid actuated check valve

$107 \mid 10-12$ | 2

\section{Study of solenoid coil}

To find the pulling force required by the solenoidactuator for check valve, the moments about check valve door were taken (Fig. 2). The load acting on the check valve door were assumed as $0.98 \mathrm{~N}$ which was $100 \mathrm{gm}$ of seed weight held by it. To support this load, $1.17 \mathrm{~N}$ force is required on check valve door arm at the other side. Based on these, the commercially available linear solenoid actuator was selected (Fig. 3), which can exert the pulling force of $6 \mathrm{~N}$ and stroke length of $10 \mathrm{~mm}$ and works on 12 $\mathrm{V}, 1 \mathrm{~A}$ of DC Current.

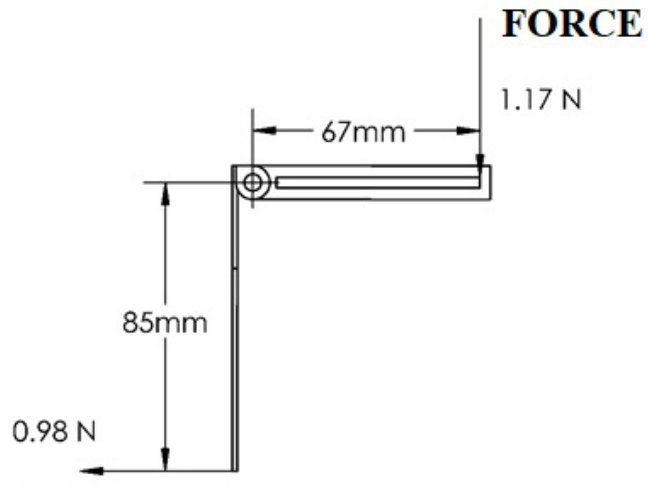

\section{LOAD}

Figure. 2 Moment diagram of check valve door Testing of solenoid-actuated check valve with experimental test rig

The developed electro-mechanic seed metering drive system was tested with an opto electronic measurement system for $\mathrm{CO} 6$ variety of maize seed. Opto electronic measurement system equipped with Infrared sensor system consists 3 pairs of infrared transmitting and receiving tubes. Functional block diagram of system is shown in Fig. 4. The effective sensing distance range was 2 to $30 \mathrm{~cm}$ and detection angle was $35^{\circ}$. The infra-red sensor was placed at minimum height from greased belt (20 to $50 \mathrm{~mm}$ ) to reduce the errors of seed spacings by seed dropping height. Computer was equipped with open-source Arduino IDE through UART serial communication protocol. It records the signals from the rotary encoder and infra-red sensor system. By analyzing the recorded data, the seed spacings were measured.

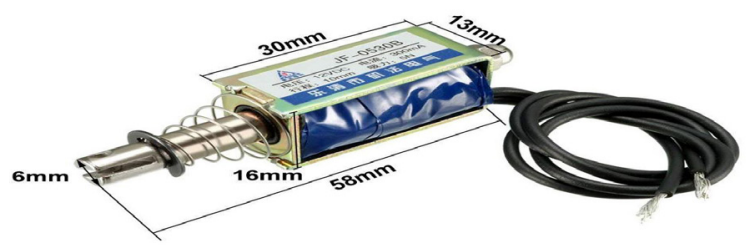

Figure. 3 Linear solenoid actuator 


\section{Calibration of testing platform}

For successful measurements by opto electronic measurement system on developed electro mechanic seed metering system, it was compared with the measurements taken by sticky belt test rig. In this procedure, the testing platform was operated with a belt speed of $1.5 \mathrm{~km} \mathrm{~h}^{-1}$, inclined metering plate speed of 0.10 to $0.20 \mathrm{~m} \mathrm{~s}^{-1}$ with the seed space varying from 5 to $45 \mathrm{~cm}$. The seed spacing values measured on sticky belt using measuring scale and digital caliper taken as reference values. The relationship was analyzed between greased belt and opto-electronic system readings (Karayel et al., 2006; Kocher et al., 1998; Lan et al., 1999). The coefficient of determination, mean absolute percentage error, absolute difference, intercept and slope were found out for CO 6 variety of maize seed by linear regression respectively as $0.9982,2.21$, $0.3882,-0.191$ and 0.99982 .

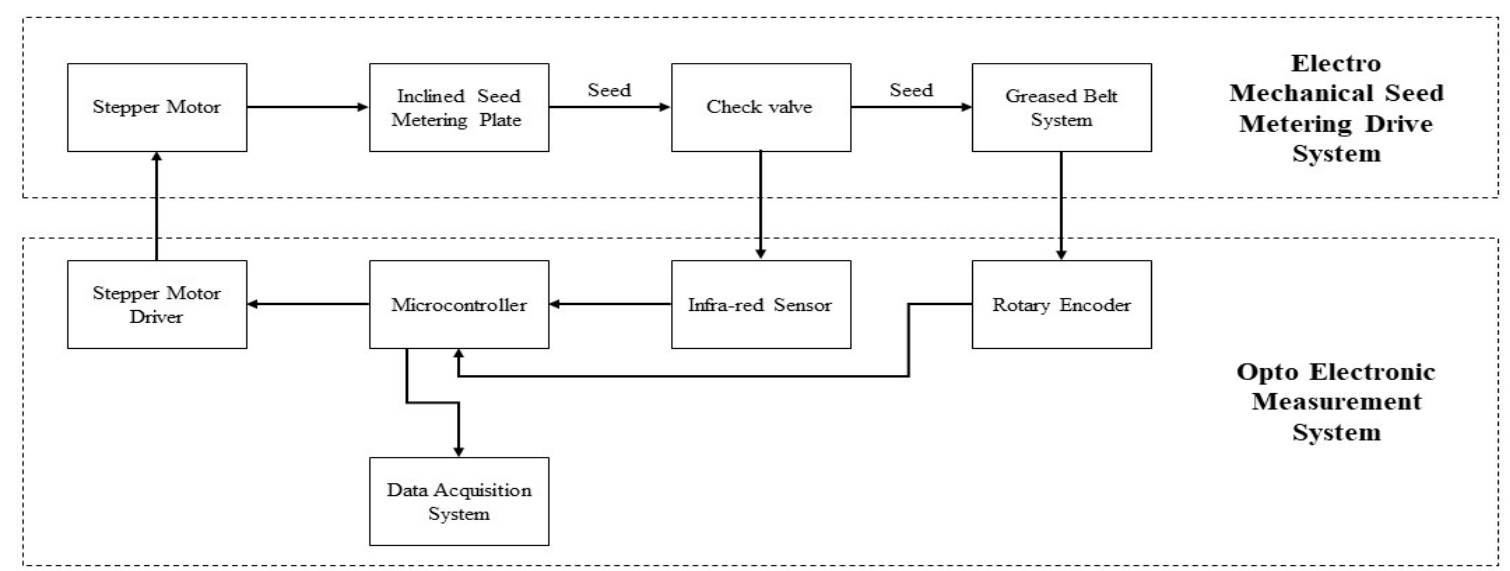

Figure. 4 Functional block diagram of test rig equipped with opto electronic measurement system

\section{Testing of developed solenoid-actuated check valve with electro-mechanic metering system}

The proposed electro mechanic drive system for inclined plate metering system was tested in opto electronic planter testing platform equipped with greased belt system which enables the testing of metering system in various levels of travelling speed and metering plate speed. Schematic diagram of testing platform with inclined plate metering system and opto electronic measurement system is shown in Fig. 5.

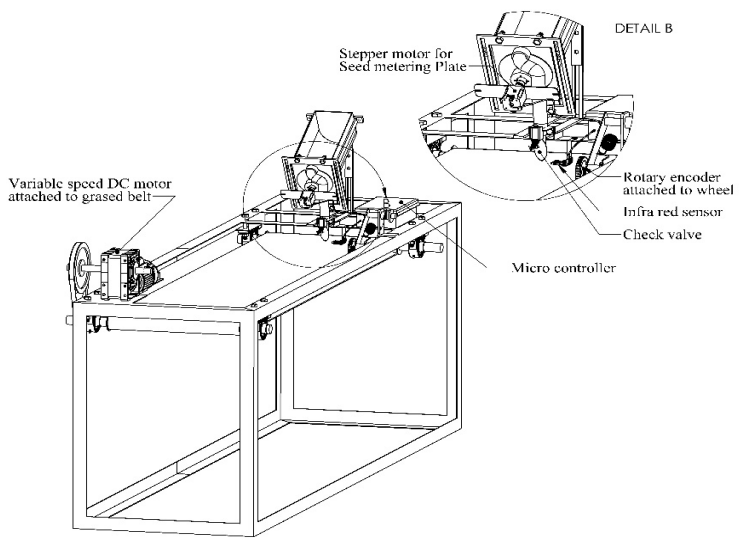

Figure. 5 Schematic diagram of testing platform with inclined plate metering system and opto electronic measurement system

The proposed electro-mechanic inclined plate metering system performance was tested in four different travelling speed of operations (Ts) (1, 2, 3 and $4 \mathrm{~km} \mathrm{~h}^{-1}$ ), check valve opening times (Ci) 75, 100 $\mathrm{ms}$ at $95 \mathrm{~mm}^{2}$ cell area of inclined metering plate. The inclination of seed metering plate to horizontal was kept as $60^{\circ}$.

Multiple index $\left(\mathrm{I}_{\text {multi }}\right)$, miss index $\left(\mathrm{I}_{\text {miss }}\right)$, precision index $\left(I_{p}\right)$ and quality of feed index $\left(I_{q f}\right)$ were used to determine the performance of proposed electromechanic drive system. Good performance of system is indicated by higher $I_{\text {qf }}$ value and lower $I_{\text {multi }}, I_{\text {miss }}, I_{p}$ values. These values were calculated by following equations as related standards (Cay et al., 2018) (ISO 7256-1:1984(E) Standard, 1984).

$$
\begin{gathered}
I_{\text {mult }}=\frac{n_{1}}{N} \times 100 \\
I_{\text {miss }}=\frac{n_{2}}{N} \times 100 \\
I_{p}=\frac{S_{d}}{Z_{t}} \times 100 \\
I_{a f}=100-\left(I_{\text {mult }}+I_{\text {miss }}\right)
\end{gathered}
$$

here $Z_{t}$ is the theoretical set value of seed spacing, $N$ is the total number of seed spacing, $n_{1}$ is the number of multiple seeds from 0 to $0.5 Z_{t}$, $\mathrm{n}_{2}$ is the number of missing seeds from $1.5 \mathrm{Z}_{\mathrm{t}}$ to $\infty$ and $S_{d}$ is standard deviation of seed spacing values. Minitab 17 statistical software (StatSoft, Inc. Tulsa OK, USA) was used for data analysis. 


\section{RESULTS AND DISCUSSION}

The relation between four levels of travelling speed of planter and quality of feed index $\left(I_{\mathrm{qf}}\right)$, missing index $\left(\mathrm{I}_{\text {miss }}\right)$, multiple index $\left(\mathrm{I}_{\text {multi }}\right)$ and precision index $\left(I_{p}\right)$ at two levels of check valve opening times for $\mathrm{CO}$ 6 maize variety is shown in Fig. 4.

It was observed as $\mathrm{I}_{\mathrm{af}}$ value higher at check valve opening times of $75 \mathrm{~ms}$ as $89.6,89.3,88.3,86.7$ $\%$ at 1, 2, 3, $4 \mathrm{~km} \mathrm{~h}^{-1}$ travelling speed respectively. Lower $\mathrm{I}_{\mathrm{af}}$ value was observed at check valve opening time of $100 \mathrm{~ms}$ as $88.6 \%, 88.5 \%, 87.8 \%, 86.2 \%$ at $1,2,3,4 \mathrm{~km} \mathrm{~h}^{-1}$ travelling speed respectively. It was observed at check valve opening time of 75 ms as $0.3 \%$ decrease in $I_{\text {of }}$ when travelling speed increased from 1 to $2 \mathrm{~km} \mathrm{~h}^{-1}, 1.1 \%$ decrease in I when travelling speed increased from 2 to $3 \mathrm{~km} \mathrm{~h}^{-1}$, $1.8 \%$ decrease in $\mathrm{I}_{\mathrm{af}}$ when travelling speed increased from 3 to $4 \mathrm{~km} \mathrm{~h}^{-1}$. From the reading it was observed that as the forward speed increases, quality feed index decreased for all the levels of check valve opening times (Fig. 5). It was observed that increase of travelling speed from 3 to $4 \mathrm{~km} \mathrm{~h}^{-1}$ shows greater

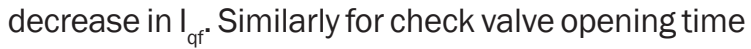
of $100 \mathrm{~ms}$, the decrease of $\mathrm{I}_{\mathrm{qf}}$ was observed as $1.8 \%$ when travelling speed increased from 3 to $4 \mathrm{~km} \mathrm{~h}^{-1}$.
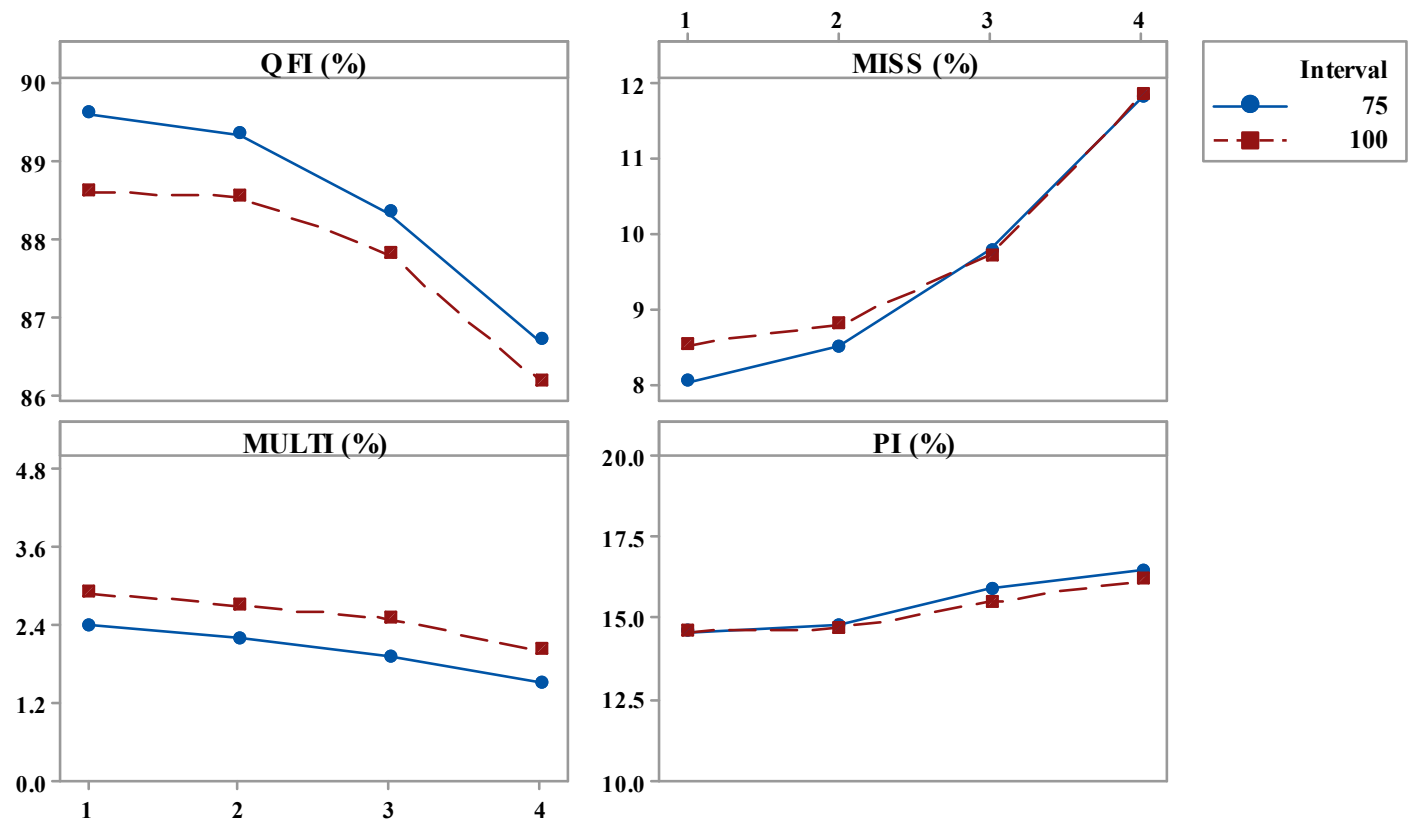

Travel Speed $(\mathrm{km} / \mathrm{h})$

\section{Figure. 6 Relation between four levels of travelling speed of planter and various indices at two levels of check valve opening times for CO 6 maize variety}

The missing index was observed lower at check valve opening time of $75 \mathrm{~ms}$ as $8 \%, 8.5 \%, 9.8$ $\%, 11.8 \%$ at $1,2,3,4 \mathrm{~km} \mathrm{~h}^{-1}$ travelling speed respectively. Higher $\mathrm{I}_{\text {miss }}$ value was observed at check valve opening time of $100 \mathrm{~ms}$ as $8.5 \%$, $8.8 \%, 9.7 \%, 11.8 \%$ at $1,2,3,4 \mathrm{~km} \mathrm{~h}^{-1}$ travelling speed respectively. It was observed at check valve opening time of $75 \mathrm{~ms}$ as $6.3 \%$ increase in $\mathrm{I}_{\text {miss }}$ when travelling speed increased from 1 to $2 \mathrm{~km} \mathrm{~h}^{-1}, 15.3 \%$ increase in $\mathrm{I}_{\text {miss }}$ when travelling speed increased from 2 to $3 \mathrm{~km} \mathrm{~h}^{-1}, 20.4 \%$ increase in $\mathrm{I}_{\text {qf }}$ when travelling speed increased from 3 to $4 \mathrm{~km} \mathrm{~h}^{-1}$ (Fig. 5). It was observed that an increase of travelling speed from 3 to $4 \mathrm{~km} \mathrm{~h}^{-1}$ showed greater increase in $\mathrm{I}_{\text {miss }}$ as similar to $\mathrm{I}_{\mathrm{qf}}$. Similarly, for check valve opening time of 100 $\mathrm{ms}$, the increase of $\mathrm{I}_{\text {miss }}$ was observed as $21.6 \%$ when travelling speed increase from 3 to $4 \mathrm{~km} \mathrm{~h}^{-1}$.
It was observed that all levels of travelling speed and check valve opening time does not influence the multiple index. For all levels of treatment, $I_{\text {multi }}$ was observed as 1.9 to $2.9 \%$. The precision index was observed at check valve opening time of 75 ms as $14.6 \%, 14.8 \%, 15.9 \%, 16.5 \%$ at 1, 2, 3, 4 $\mathrm{km} \mathrm{h}^{-1}$. The I was observed at check valve opening time of $100 \mathrm{~ms}$ as $14.6 \%, 14.7 \%, 15.5 \%, 16.2 \%$ at $1,2,3,4 \mathrm{~km} \mathrm{~h}^{-1}$. It was observed at check valve opening time of $75 \mathrm{~ms}$ as $1.4 \%$ increase in I when travelling speed increased from 1 to $2 \mathrm{~km} \mathrm{~h}^{-1}, 7.4 \%$ increase in $\mathrm{I}_{\mathrm{p}}$ when travelling speed increased from 2 to $3 \mathrm{~km} \mathrm{~h}^{-1}, 3.8 \%$ increase in I when travelling speed increased from 3 to $4 \mathrm{~km} \mathrm{~h}^{-1}$ (Fig. 5). It was observed that an increase in travelling speed from 2 to $3 \mathrm{~km} \mathrm{~h}^{-1}$ showed greater increase in $\mathrm{I}_{\mathrm{p}}$ as similar as $\mathrm{I}_{\mathrm{qf}}$. Similarly, at check valve opening time of 100

$107 \mid 10-12$ | 4 
$\mathrm{ms}$, the increase of $\mathrm{I}_{\mathrm{p}}$ was observed as $5.4 \%$ when travelling speed increase from 2 to $3 \mathrm{~km} \mathrm{~h}^{-1}$.

\section{CONCLUSION}

The linear solenoid actuator operated check valve was developed and evaluated to increase the precision of seed placement of inclined plate seed metering mechanism. The solenoid actuated check valve was tested with opto electronic measurement system in laboratory conditions. For $\mathrm{CO} 6$ variety of maize seeds, the quality feed index, missing index, multiple index and precision index found out as $86.2-89.6 \%, 8-11.8 \%, 1.9-2.9 \%$ and 14.6 to $16.5 \%$, respectively. Precision index of developed electro-mechanic metering system (14.6 - $16.5 \%)$ was increased by solenoid actuated check valves. It was higher when compared to an electro mechanic drive system without check valves (8.79 - $22.14 \%$ ) (Cay et al., 2018). Due to the easier adaptation of electro-mechanic drive system by metering systems, it can be easily fixed with higher precision planting systems.

\section{FUNDING AND ACKNOWLEDGMENT}

The data used in this work comprise a part of the research project supported by the Council of Scientific and Industrial Research, New Delhi, India. In addition, authors are thankful to Council of Scientific and Industrial Research, New Delhi, India for supporting this research project.

\section{ETHICS STATEMENT}

No specific permits were required for the described field studies because no human or animal subjects were involved in this research.

\section{CONSENT FOR PUBLICATION}

All the authors agreed to publish the content.

\section{COMPETING INTERESTS}

There were no conflict of interest in the publication of this content

\section{REFERENCES}

Bainer, R., Kepner, R. A., \& Barger, E. L. (1956). Principles of farm machinery (Vol. 81, Issue 2). LWW.

Cay, A., Kocabiyik, H., \& May, S. (2018). Development of an electro-mechanic control system for seed- metering unit of single seed corn planters Part I: Design and laboratory simulation. Computers and Electronics in Agriculture, 144(August 2017), 71-79. https://doi.org/10.1016/j. compag.2017.11.035

Gautam, P. V. (2017). Development of microcontroller based seed metering mechanism for planting of pulse crops. ICAR-INDIAN AGRICULTURAL RESEARCH INSTITUTE NEW DELHI.

lacomi, C., \& Popescu, O. (2015). A New Concept for Seed Precision Planting. Agriculture and Agricultural Science Procedia, 6, 38-43. https:// doi.org/10.1016/j.aaspro.2015.08.035

ISO 7256-1:1984(E) Standard. (1984). Sowing equipment-test methods e Part one, single seed drills (precision drills). International Organisation for Standardization. Geneva, Switzerland.

Karayel, D., Wiesehoff, M., Özmerzi, A., \& Müller, J. (2006). Laboratory measurement of seed drill seed spacing and velocity of fall of seeds using high-speed camera system. Computers and Electronics in Agriculture, 50(2), 89-96. https:// doi.org/10.1016/j.compag.2005.05.005

Kocher, M. F., Lan, Y., Chen, C., \& Smith, J. A. (1998). Opto-electronic sensor system for rapid evaluation of planter seed spacing uniformity. Transactions of the American Society of Agricultural Engineers, 41(1), 237-245. https://doi. org/10.13031/2013.17143

Lan, Y., Kocher, M. F., \& Smith, J. A. (1999). Opto-electronic sensor system for laboratory measurement of planter seed spacing with small seeds. Journal of Agricultural and Engineering Research, 72(2), 119127. https://doi.org/10.1006/jaer.1998.0353

Liang, Z., Zhang, D., Yang, L., Cui, T., \& Hao, Y. (2015). Experimental study on motor driven pneumatic precision seed-metering device for maize. American Society of Agricultural and Biological Engineers Annual International Meeting 2015, 5, 3945-3952. https://doi.org/10.13031/aim.20152189758

Özmerzi, A., Karayel, D., \& Topakci, M. (2002). Effect of sowing depth on precision seeder uniformity. Biosystems Engineering, 82(2), 227-230. https:// doi.org/10.1006/bioe.2002.0057

Singh, I., Gautam, A., Dixit, A. K., Manes, G. S., \& Singh, A. (2020). Development and Evaluation of Inclined Plate Metering Mechanism for the Sowing of Maize (Zea mays L) Seed. Current Journal of Applied Science and Technology, June, 118-128. https:// doi.org/10.9734/cjast/2020/v39i1330689 